\title{
PEGylated recombinant human soluble tumour necrosis factor receptor type I (r-Hu-sTNF-RI): novel high affinity TNF receptor designed for chronic inflammatory diseases
}

\author{
Carl K Edwards, III
}

\begin{abstract}
The proinflammatory cytokine, tumour necrosis factor $\alpha$ (TNF $\alpha$ ) has been shown to play a pivotal part in mediating acute and chronic inflammation. The activities of TNF $\alpha$ are modulated by the proteolytic shedding of the soluble extracellular domains of the two TNF receptors, p55 sTNF-RI and p75 sTNF-RII. Amgen Inc has cloned and expressed a recombinant form of a natural inhibitor of $T N F \alpha$, referred to as recombinant human soluble TNF receptor type I (r-Hu-sTNF-RI, sTNF-RI). STNF-RI is an $E$ coli recombinant, monomeric form of the soluble TNF-type I receptor. A high molecular weight polyethylene glycol (PEG) molecule is attached at the $\mathrm{N}$-terminus position to form the molecule intended for clinical evaluations (PEG sTNF-RI). Preclinical studies to date demonstrate that PEG STNF-RI is efficacious in rodent models of chronic inflammatory disease including rheumatoid arthritis and Crohn's disease at doses as low as 0.3 $\mathrm{mg} / \mathrm{kg}$ given every other day. This dose results in plasma concentrations of 0.3 to
\end{abstract} $0.5 \mu \mathrm{g} / \mathrm{ml}$. Higher doses with correspondingly higher plasma concentrations yield higher efficacy. It has also demonstrated efficacy in $E$ coli lipopolysaccharide, and Staphylococcus enterotoxin B mediated models of acute inflammation in rodents and primates. Pharmacokinetic studies in mice, rats, cynomolgus monkeys, baboons, and chimpanzees have been conducted with PEG sTNF-RI. Absorption from a subcutaneous dose was slow, with the time to reach maximal plasma concentrations of 24-48 hours in rats, and in monkeys, and 3-29 hours in chimpanzees. The initial volume of distribution of PEG sTNF-RI was essentially equivalent to that of plasma $(40 \mathrm{ml} / \mathrm{kg})$. This suggests the protein does not appear to extensively distribute from the systemic circulation with a volume of distribution at steady state (Vss) less than $200 \mathrm{ml} / \mathrm{kg}$ in all species studied. These results are consistent with previous experience with PEGylated proteins in which PEGylation decreases both the rate of absorption and the plasma clearance of human recombinant proteins in animals and humans. The use of a PEG molecule will probably provide a more advantageous dosing schedule (that is, less frequent dosing) for the patient compared with a non-PEG sTNF-RI.

(Ann Rheum Dis 1999;58:(Suppl I) I73-I81)

\section{Biology overview}

REVIEW OF TUMOUR NECROSIS FACTOR ACTIVITY During the past decade, the understanding of immunopathological reactions has greatly evolved as a result of the characterisation of cytokines and interleukins that regulate the interactions not only between cells of the immune system, but also between the immune system and other tissues and cells, such as endothelial cells, fibroblasts, and adipocytes. One cytokine that is increasingly recognised as a central mediator in a wide spectrum of physiological and immune functions is macrophage derived tumour necrosis factor $(\mathrm{TNF} \alpha)$ or cachectin. Although much remains to be elucidated about this molecule, $\mathrm{TNF} \alpha$ has been found to mediate effects as diverse as tumoricidal activity, ${ }^{1}$ wasting associated with chronic disease, ${ }^{2}$ and the recruitment of both immune and non-immune cells to participate more effectively in the host response to an invasive agent. In addition, an increasingly large body of evidence indicates that $\mathrm{TNF} \alpha$ serves as an important mediator in the evolution of acute ${ }^{3}$ and chronic inflammatory diseases. ${ }^{45}$

As stated in the introduction, $\mathrm{TNF} \alpha$ is also referred to as cachectin, ${ }^{6}$ and this cytokine has a wide range of biological effects. ${ }^{37}$ These effects include anti-tumour activity, ${ }^{36}$ mediation of endotoxic shock and cachexia in infectious disease, ${ }^{89}$ augmentation of superoxide anion $\left(\mathrm{O}_{2}^{-}\right)$and hydrogen peroxide $\left(\mathrm{H}_{2} \mathrm{O}_{2}\right)$ release by neutrophils and macrophages, ${ }^{10}$ inhibition of viral replication, and potentiation of non-viral pathogen destruction by macrophages in vitro and in vivo. ${ }^{2}$ These studies and numerous others point out that $\mathrm{TNF} \alpha$ is a major physiological cytokine important in mediating normal homeostatic mammalian processes. ${ }^{5} 11$

$\mathrm{TNF} \alpha$ exists as a trimer of three identical subunits. ${ }^{10} 1213$ Signal transduction occurs when $\mathrm{TNF} \alpha$ binds to, and dimerises two receptors of either the p55 (TNF-RI) or p75 (TNF-RII) subtype on the cell surface. ${ }^{14}$ Numerous biological effects of $\mathrm{TNF} \alpha$ are mediated following intracellular signalling with the high affinity p55 TNF receptor (TNF-RI). ${ }^{15}$ Naturally occurring TNF $\alpha$ inhibitors, consisting of the full length 4 domain or truncated forms of the extracellular region of TNF-RI, ${ }^{16}$ are referred to as tumour necrosis factor binding proteins (TNFbp) or soluble 
TNF receptor (sTNF-RI). These molecules have been found in active human rheumatoid arthritic disease tissue, serum, synovial fluid, and synovial explant cultures. The presence of sTNF-RI has been shown to correlate to rheumatoid arthritis (RA) disease activity. ${ }^{17}$

Recombinant human soluble tumour necrosis factor receptor type I (sTNF-RI) has been cloned and isolated by recombinant DNA techniques using $E \operatorname{coli}^{18}{ }^{19}$ as a host. Numerous preclinical animal model studies designed to test the efficacy of PEG sTNF-RI have demonstrated reproducible, potent antiinflammatory, anti-cytokine, and bone and cartilage sparing effects. ${ }^{20-23}$

A wide array of biological agents have been designed to inhibit $\mathrm{TNF} \alpha$, including specific anti-human $\mathrm{TNF} \alpha$ monoclonal antibody, ${ }^{24-26}$ soluble TNF receptor fusion constructs, ${ }^{19} 2728$ and soluble TNF receptor binding proteins. ${ }^{27-31}$ Several synthetic inhibitors of $\mathrm{TNF} \alpha$ biosynthesis have also been described. ${ }^{7233}$

The use of soluble TNF receptors, or TNF binding proteins, has also recently been tested in animal models and in the clinic. ${ }^{30}{ }^{34-37}$ It has been postulated that TNF-RI and TNF-RII normally function as TNF buffers and slow release reservoirs, depending on the relative concentrations of TNF and the respective biochemical properties of the two receptors. ${ }^{38} 39$ These very different kinetics of binding of $\mathrm{TNF} \alpha$ to the two TNF receptors has raised speculation that in vivo, the two receptors may have fundamentally different functions. The TNF type II receptor may serve as a "ligand passer"- that is, a means to deliver or pass $\mathrm{TNF} \alpha$ to the type I receptor for signalling when concentrations of TNF $\alpha$ are low. ${ }^{40}$ Support for this hypothesis that the primary function of the TNF type II receptor is a ligand passer is the observation that under in vivo conditions, the primary inflammatory responses to soluble 17 $\mathrm{k}_{\mathrm{D}} \mathrm{TNF} \alpha$ are mediated by TNF-RI, and not TNF-RII signalling. ${ }^{41}$ Because of the higher affinity with the TNF type I receptor greater potential clinical benefit may be realised. ${ }^{15} 3642$

The balance or imbalance between cytokines and their natural inhibitors seems to play a very important part in RA. ${ }^{43}$ As RA is a long term chronic disease, any therapeutic agent designed to alleviate the inflammation and downstream destruction in the joint must be efficacious for a number of years after multiple administrations to the patient.

\section{Evidence that TNF $\alpha$ is a mediator of clinical diseases}

$\mathrm{TNF} \alpha$, a polypeptide cytokine, was discovered on the basis of its induction of haemorrhagic necrosis in certain murine tumours in vivo, and, independently, as a bloodborne mediator of cachexia during parasitic disease. ${ }^{7}$ It is produced by activated macrophages, $\mathrm{T}$ cells, and other cells, and has many activities in the immune system and in other systems. $\mathrm{TNF} \alpha$ is a potent molecule that stimulates the production of many cytokines, including IL1, IL6, GM-CSF, IL8, and secretion of degradatory molecules including several metalloproteinases. ${ }^{33} 44$ TNF mediates the cytokine cascade that causes inflamma- tion and joint destruction in RA. ${ }^{45}{ }^{46} \mathrm{TNF} \alpha$ concentrations are increased in rheumatoid synovial fluids, particularly in patients with severe disease or with high concentrations of white blood cells in the synovial fluid. ${ }^{17}{ }^{47} \mathrm{TNF}$ is abundant in macrophages in the rheumatoid synovial membrane and TNF containing cells are localised to the pannus (articular cartilage in the joints of patients with RA), suggesting production near the site of tissue destruction. ${ }^{48}$ Furthermore, TNF receptors are localised to macrophages and fibroblasts in the rheumatoid synovial lining layer, as well as to lymphocytes and endothelial cells in the subsynovial membrane, which suggests that a variety of cells in the rheumatoid synovial membrane are potential targets for $\mathrm{TNF}^{49}{ }^{50}$

As stated previously, two distinct TNF receptors (TNFRs) have been identified: the $75 \mathrm{k}_{\mathrm{D}}$ or p75 receptor type II and the $55 \mathrm{k}_{\mathrm{D}}$ or p55 receptor type I (formerly referred to as p80 and p60, respectively ${ }^{13}{ }^{39}$ ). Both the TNF type-I and type-II receptors exist as cell-surface and soluble forms and both forms bind TNF, although with different affinities. ${ }^{15} 404151$ TNF cell surface receptors are present on virtually all cell types, including macrophages, lymphocytes, and neutrophils. TNF must bind to two or three cell surface receptor molecules for signalling to occur, resulting in a biological effect. Binding to a single cell surface receptor does not result in signalling.

Monomeric fragments that comprise the extracellular portion of the cell surface receptors are naturally occurring forms resulting from proteolytic cleavage, and then are referred to as soluble TNFRs (sTNFRs). ${ }^{7}$ sTNFRs are ubiquitous, and increased concentrations of sTNFRs have been found in the circulation of patients with RA. ${ }^{50} 5253$ sTNFR concentrations, measured by enzyme linked immunosorbent assay, are higher in synovial fluid samples compared with serum sample concentrations in patients with RA. ${ }^{47}$

\section{Clinical evidence that TNF $\alpha$ is a mediator of RA}

$\mathrm{RA}$ is a heterogeneous, systemic disease of unknown aetiology, and persons with RA typically develop inflammation of joint synovium. ${ }^{545}$ Clinical symptoms become apparent with progression of synovitis resulting from production and release of cytokines from activated macrophages, along with the activation of $\mathrm{T}$ lymphocytes, angiogenesis, and attraction of neutrophils to the joint cavities. Cellular expression of major histocompatibility complex (MHC) class II molecules within the joint microenvironment is a predominant feature of $\mathrm{RA}$, and this expression induces production of a complex network of cytokines. Cytokines induce synovial cell proliferation, resulting in invasion and destruction of articular cartilage. Synovial fibroblasts are thought to become activated by proinflammatory mediators such as $\mathrm{TNF} \alpha$ to secrete a large variety of cytokines and growth factors. ${ }^{46}$ Activities ascribed to $\mathrm{TNF} \alpha$ in RA include recruitment and activation of polymorphonuclear leucocytes (PMNs), cellular proliferation, increased prostaglandin and matrix 
degrading protease activity, fever, and bone and cartilage resorption. ${ }^{456}$ Rheumatoid synovial fluid seems to include predominantly macrophage derived products such as IL $1 \beta$, IL $1 \beta$, IL6, TNF $\alpha$, and IL8, although there has been disagreement over the exact cytokine composition. ${ }^{57}$ The relative cytokine composition of synovial fluid may be influenced in vivo by variables such as disease severity and stage of progression. IL8 (neutrophil chemotactic factor) may be responsible for the accumulation of neutrophils in the joint cavity, and its production may be stimulated by IL1 $\beta$ and $\mathrm{TNF} \alpha$. TNF $\alpha$ and $\mathrm{TNF} \alpha$ induced IL1 stimulate the synthesis of collagenase and stromelysin by synoviocytes, thereby contributing to the loss of normal joint integrity and function.

The concept that $\mathrm{TNF} \alpha$ is a major mediator of the inflammatory response in the affected joints of rheumatoid arthritic patients is now well recognised. Studies using cA2, a chimeric (mouse $\times$ human) Mab, have demonstrated significant effects in short-term and long term duration clinical trials (Inflixamab, Centocor, Inc) ${ }^{24}{ }^{58}$ An unexpected side effect in these trials was the development of IgM class anti-dsDNA antibodies, which has raised the question of patients developing lupus-like syndromes with long term $\mathrm{Mab}$ treatment. ${ }^{59}$ Other humanised anti-TNF $\alpha$ Mab have also been tested in the clinic with variable results. ${ }^{60}$

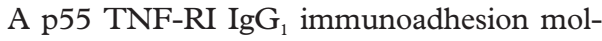
ecule demonstrated short-term efficacy in European and North American phase 2 clinical trials; however, the immunogenicity of this molecule affected drug clearance after multiple intravenous injections. ${ }^{61}$ Results from phase 2 and 3 extension studies using Enbrel, a p75 sTNF-RII $\mathrm{IgG}_{1}$ immunoadhesion molecule have been published. ${ }^{62}{ }^{63}$ These results suggest that the p75

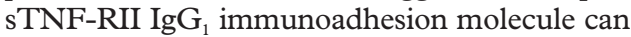
be safely administered to RA patients for at least a period of six months. ${ }^{3764}$ In a dose escalation safety study in patients with refractory RA, the administration of the p75 sTNF-RII IgG $_{1}$ immunoadhesion molecule produced no clinically significant side effects and decreased C reactive protein levels and numbers of swollen joints. ${ }^{37} 64$ These initial encouraging results were reproduced in a multicentre, placebo controlled trial. ${ }^{63}$ Seventy five per cent of patients receiving the highest dose of the p75 sTNF-RII IgG $_{1}$ immunoadhesion molecule achieved at least a $20 \%$ clinical response according to American College of Rheumatology (ACR) criteria. No antibodies against the drug were reported, although injection site reactions and upper respiratory infections were observed in several patients. This drug was previously tested in septic shock. ${ }^{35}$ Recently the pivotal phase 3 studies were published with this molecule. ${ }^{63}$

As mentioned above, the immunogenicity of the TNFbp PEGylated Dimer molecule negatively impacted the clearance rate of the molecule, and reduced the serum half life in the phase $1 / 2$ clinical trial and was therefore, determined as not suitable for a chronic indication. ${ }^{65}$ However, proof of concept was demonstrated by a decrease in swollen and tender joints over a 21 day period. ${ }^{65}$ The
TNFbp PEGylated Dimer was replaced with a second generation, monomeric sTNF-RI formulation, PEG sTNF-RI, which offers the following advantages: (1) minimal immunogenicity, (2) high degree of efficacy in animal models of RA, and (3) minimal toxicological impact in animal models. ${ }^{66}$

\section{Rationale for the design of the PEG r-Hu-sTNF-RI molecule}

Amgen previously conducted two clinical studies using another high affinity soluble TNFtype I receptor ( $\mathrm{r}-\mathrm{HuTNFbp}$ PEGylated Dimer, TNFbp Dimer). ${ }^{65}$ In the initial study, human anti-TNFbp antibodies were generated after a single intravenous dose in normal volunteers. In RA patients the TNFbp Dimer demonstrated preliminary efficacy after single and multiple doses, however, the appearance of antibodies correlated with increased clearance and shorter half life after multiple doses. These antibodies were neither neutralising nor cytotoxic. Further development of the TNFbp PEGylated Dimer for a chronic indication such as RA became a concern because of the immunogenicity of this molecule. ${ }^{65}$

Amgen initiated several studies to identify and develop backup and second generation soluble TNF-type I receptors. These studies included:

1 Investigation of the primary antigenic epitopes of the TNFbp Dimer,

2 Assessment of whether truncation of the sTNF-RI molecule resulted in decreased immunogenicity in rodent and primate models,

3 Determination of whether MonoPEGylated or MultiPEGylated sTNF-RI analogues were less immunogenic in primates,

4 Determination of whether PEGylation location affected immunogenicity,

5 Sequencing of the primate p55 and p75 TNF-R proteins and determined the homology of these structures to the recombinant human TNF-RI receptor,

6 Development of an in vitro solution phase ELISA assay to use in predicting the relative antigenicity of sTNF-RI analogues in humans,

7 Answering the scientific issues regarding possible neutralising and cytotoxic effects of anti-TNFbp antibodies,

8 Studying the pharmacokinetics of TNFbp Dimer after single and repeated administration in the previous clinical trials, and

9 Testing the various analogues in pharmacokinetic, toxicology, and pharmacology studies. At the conclusion of these studies, Amgen selected PEG sTNF-RI as the optimal molecule for clinical evaluation. This molecule was chosen because it demonstrated a favourable pharmacokinetic profile based upon parameters such as bioavailability, plasma clearance, and terminal half life. ${ }^{66}$ It was also the least immunogenic and antigenic molecule, and demonstrated efficacy in animal models that have been previously used to predict activity of agents currently used in treatment of RA. Thus PEG sTNF-RI was designated as the clinical candidate (fig 1 ). 


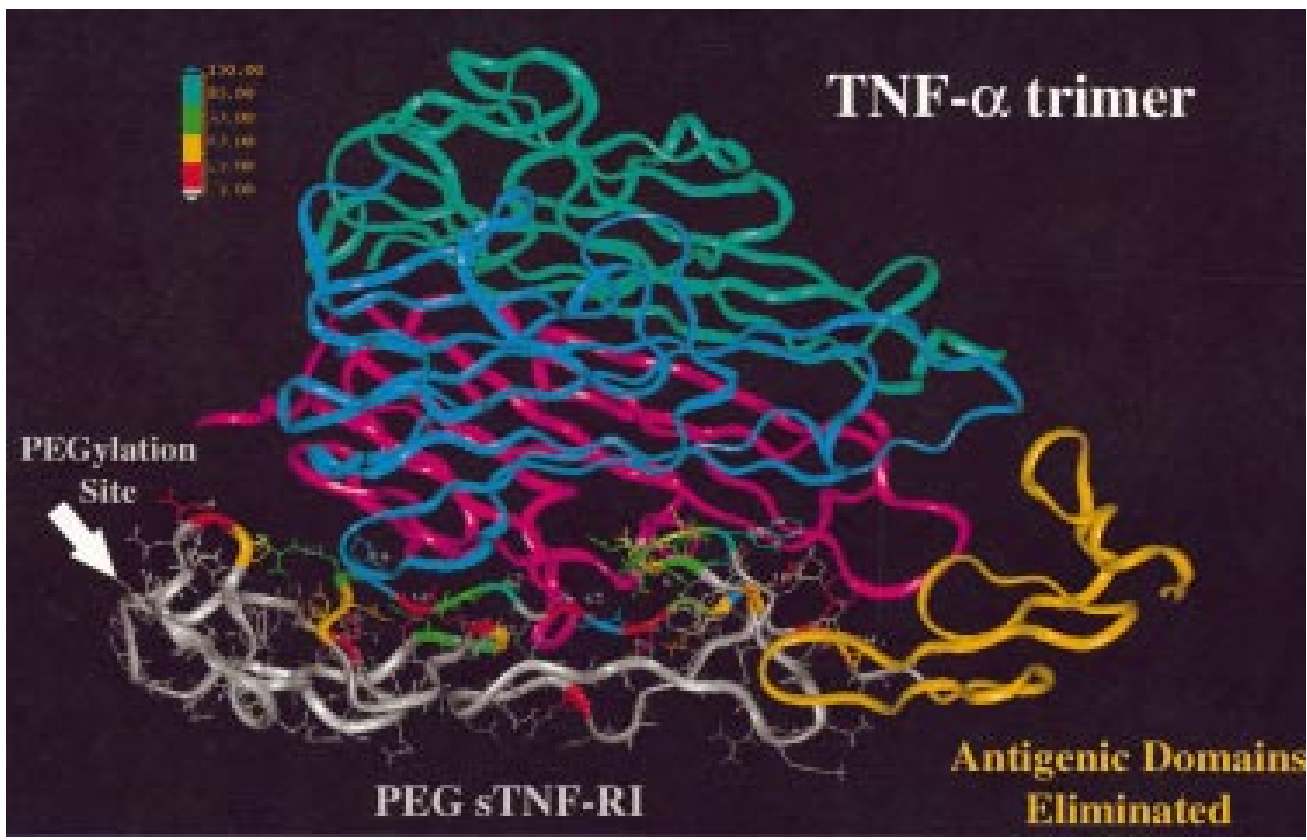

Figure 1 PEG sTNF-RI/TNFa complex.

\section{In vitro activity of the PEG r-Hu-sTNF-RI}

PEG STNF-RI L929 CYTOTOXICITY ASSAY RESULTS The L929 Bioassay ${ }^{67}$ was used to test the activity of PEG sTNF-RI (table 1). The reference standards used for PEG sTNF-RI were the unPEGylated (r-Hu-TNFbp) and r-HuTNF-bp PEGylated Dimer. The data show that the PEG sTNF-RI is active and, when compared with the standards, has comparable specific activities and $\mathrm{EC}_{50}$ (effective concentration) values within the range of the standard.

PEG STNF-RI RHEUMATOID ARTHRITIC EXPLANT SYNOVIAL CELL BIOASSAY RESULTS

The efficacy of PEG sTNF-RI at the cellular and molecular level was assessed in an ex vivo synovial cell bioassay using RA patient target tissue and tissue similar to synovial cells in the affected joint.$^{68}$ In this assay system, TNF $\alpha(10$ $\mathrm{ng} / \mathrm{ml}$ ) is added to the cells in vitro and inflammatory products such as prostaglandin $\mathrm{E}_{2}$ $\left(\mathrm{PGE}_{2}\right)$ and matrix metalloproteinase 1 (MMP-1) are measured by ELISA at +24 hours of cell culture. In this assay system, PEG sTNF-RI displayed dose related inhibition of TNF $\alpha$ induced $\mathrm{PGE}_{2}$ production with an $\mathrm{IC}_{50}$ (inhibitory concentration) of $25 \mathrm{nM}$ (fig 2). A purified control preparation of the human TNF Type I receptor resulted in an $\mathrm{IC}_{50}$ of $>85$ (fig 2). These data demonstrate similar activities with both receptor preparations.

Table 1 L929 cytotoxicity bioassay results

\begin{tabular}{llc}
\hline Form of molecule & $\begin{array}{l}\text { Average specific activity } \\
\text { mean (SEM) (mg/mg) }\end{array}$ & $\begin{array}{l}\text { Average sample EC } \\
\text { mean (SEM) (ng/ml) }\end{array}$ \\
\hline $\begin{array}{l}\text { Data obtained from triplicate tests } \\
\quad \text { r-HuTNFbp PEGylated Dimer }\end{array}$ & $1.2(0.06)$ & $0.94(0.04)$ \\
$\quad$ PEG r-Hu sTNF-RI & $0.88(0.18)$ & $257.6(62)$ \\
$\begin{array}{l}\text { Internal controls: data obtained from multiple tests } \\
\text { r-HuTNFbp PEGylated Dimer }\end{array}$ & $0.93(0.06)$ & $0.99(0.11)$ \\
r-HuTNFbp & $0.87(0.18)$ & $404.9(190.8)$ \\
\hline
\end{tabular}

BINDING AFFINITY PROPERTIES OF PEG STNF-RI It was recently shown that the p55 TNF receptor type I (TNF-RI) is the high affinity receptor for soluble TNF. ${ }^{15}$ To determine the ability of PEG sTNF-RI to bind to recombinant human $\mathrm{TNF} \alpha$, a BIAcore ligand binding assay was used. $^{51}$ As shown in table 2, PEG sTNF-RI binds TNF $\alpha$ with high affinity $\left(\mathrm{K}_{\mathrm{D}}=557 \mathrm{pM}\right)$. The $\mathrm{K}_{\mathrm{D}}$ values of $E$ coli derived and CHO cell derived sTNF-RI are $794 \mathrm{pM}$ and $338 \mathrm{pM}$ respectively (table 2). Finally, as previously shown, ${ }^{51}$ the dimeric form of sTNF-RI ( $r-$ HuTNFbp PEGylated Dimer) has a higher binding affinity $\left(\mathrm{K}_{\mathrm{D}}=240 \mathrm{pM}\right)$ than either the recombinant $E$ coli derived or $\mathrm{CHO}$ cell derived forms of sTNF-RI (table 2).

PEG R-HU-STNF-RI IN THE ADJUVANT ARTHRITIS MODEL

Immunisation of rats with Freund's complete adjuvant (day 0 ) causes an immunologically mediated polyarthritis with histological features resembling those of human RA. ${ }^{21}$ Onset of clinical arthritis usually occurs on day 9 . The PEG sTNF-RI was given subcutaneously every other day (Q2D) on days 9, 11, and 13. Diameter of the ankle joints was measured with a caliper on day 8 or 9 and from days 11 to 15; body weights were also determined on these days. Blood was collected on day 11 before dosing for determination of serum PEG sTNF-RI concentrations. All animals were killed on day 15, blood was collected for determination of serum PEG sTNF-RI concentrations, and hind paws and spleens were removed, weighed, and processed for histopathological evaluation.

Treatment with PEG sTNF-RI significantly inhibited the body weight effects of adjuvant disease (fig 3) and the diameter of ankle joints over the course of arthritis (expressed as area under the curve (AUC), \% inhibition) (fig 4). 


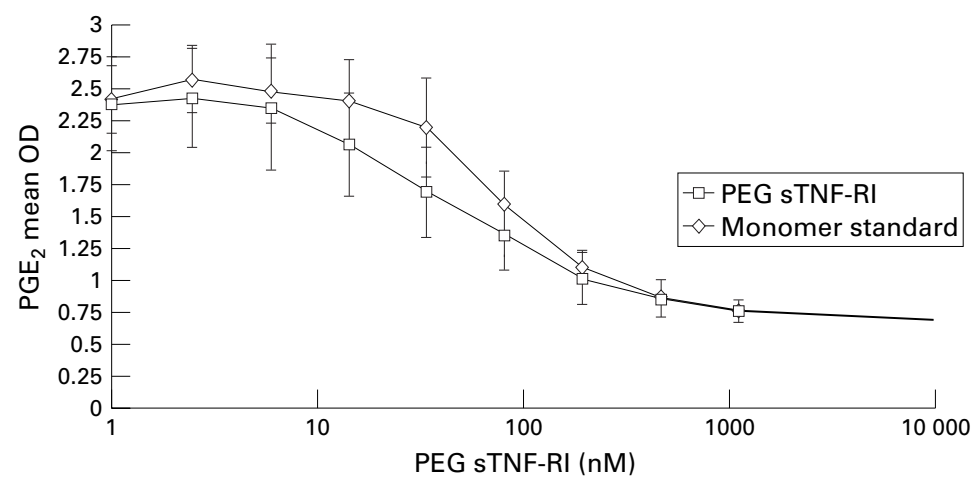

Figure 2 Dose related inhibition of human synovial fibroblast derived $P G E_{2}$ using $P E G$ $s T N F-R I$.

Table 2 Dissociation constants $\left(K_{D}\right)$ of TNFa binding to various $s$ TNF-RIs

\begin{tabular}{ll}
\hline Receptor type & $K_{D}(p M)$ \\
\hline PEG sTNF-RI & 557 \\
E coli derived 4.0 domain sTNF-RI & 794 \\
CHO cell derived 4.0 domain sTNF-RI & 338 \\
r-HuTNFbp PEGylated Dimer & 240
\end{tabular}

The binding of TNF $\alpha$ to various sTNF-RI was measured by the BIAcore chips coated with each of the sTNF-RI forms. $\mathrm{K}_{\mathrm{D}}$ values were determined from Scatchard analysis of the binding data

Compared with vehicle treated animals, treatment with PEG sTNF-RI at $9 \mathrm{mg} / \mathrm{kg}$ or 3 $\mathrm{mg} / \mathrm{kg}$ reduced the final paw weights by $57 \%$ and $45 \%$, respectively, and reduced the relative

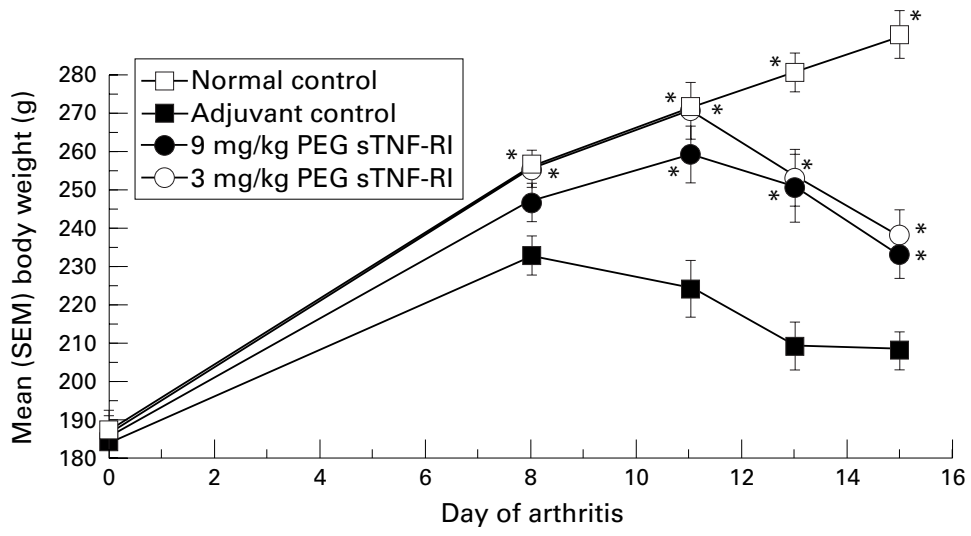

Figure 3 Effects of PEG sTNF-RI on adjuvant arthritis induced weight loss in male Lewis rats.

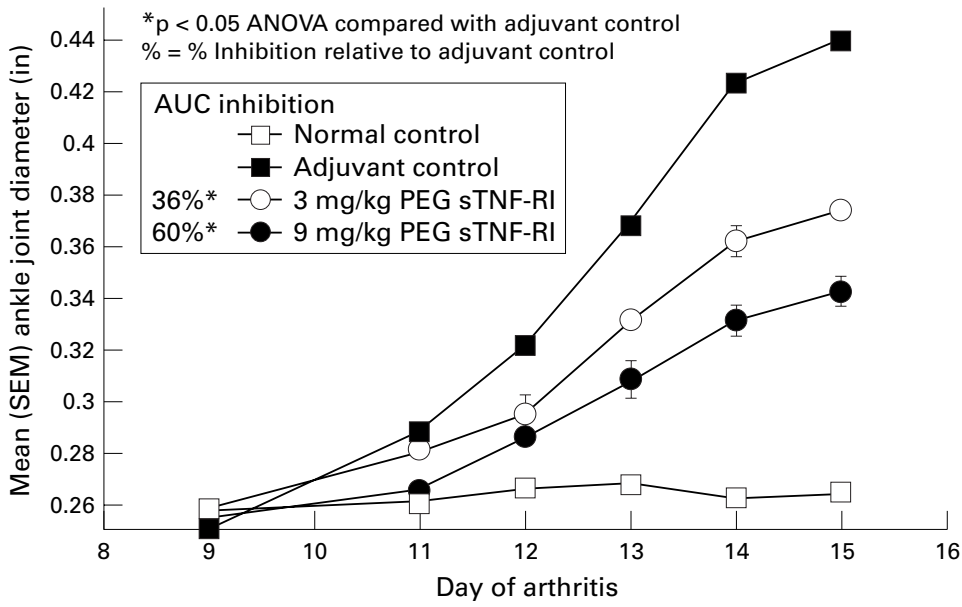

Figure 4 Effects of PEG sTNF-RI on ankle joint diameter in adjuvant arthritis in male Lewis rats. spleen weights by $58 \%$ and $59 \%$, respectively. On day 11 , concentrations of PEG sTNF-RI in serum in the $9 \mathrm{mg} / \mathrm{kg}$ and $3 \mathrm{mg} / \mathrm{kg}$ groups were $($ mean $(\mathrm{SEM})) 10.4(0.5) \mu \mathrm{g} / \mathrm{ml}$ and $3.2(0.2)$ $\mu \mathrm{g} / \mathrm{ml}$, respectively. On day 15 , concentrations of PEG sTNF-RI in serum were 12.2 (1.1) $\mu \mathrm{g} / \mathrm{ml}$ and $4.0(0.2) \mu \mathrm{g} / \mathrm{ml}$, respectively. On histopathological analysis, treatment with PEG sTNF-RI significantly reduced the amount of inflammation and bone resorption in the ankle joints of treated rats compared with vehicle treated rats (fig 5).

An additional dose response study of PEG sTNF-RI was done in this model to evaluate the potential efficacy of lower doses. Arthritic rats given subcutaneous doses of 3,1 , or 0.3 $\mathrm{mg} / \mathrm{kg}$ on days $9,11,13$ (as in previous study) had significant inhibition of final paw weights and AUC values for paw swelling. ${ }^{23}$ Histological parameters of bone resorption and inflammation were also beneficially affected by treatment with PEG sTNF-RI. ${ }^{23}$ Another set of animals were given single subcutaneous doses (3, 1 , or $0.3 \mathrm{mg} / \mathrm{kg}$ ) of PEG sTNF-RI and blood samples were obtained at intervals for determination of plasma profile associated with efficacy. These data demonstrate that plasma concentrations less than or equal to $0.5 \mu \mathrm{g} / \mathrm{ml}$ over the 48 hours of the dosing interval were associated with efficacy. Higher plasma concentrations increased the efficacy. ${ }^{23}$

PEG R-HU-STNF-RI IN THE RAT STREPTOCOCCAL INDUCED ARTHRITIS MODEL

The streptococcal cell wall (SCW) model of arthritis in female Lewis (LEW/N) rats is used to study reactivation of arthritis similar to arthritic flares in the human disease ${ }^{69}{ }^{70}$ Arthritis was induced with an intra-articular injection of SCW $(1.5 \mathrm{mg} / 10 \mathrm{ml})$ into the ankle joints. Three weeks post intra-articular injection the arthritis was reactivated by an intravenous injection of a subarthritogenic dose of SCW $(200 \mu \mathrm{g} / 200 \mu \mathrm{l})$ with drug treatment of the rats beginning one day before the reactivation. Paw swelling was assessed on days $+21,+22,+23$, and +24 . A series of studies was conducted to assess the effects of PEG sTNF-RI in this model. PEG sTNF-RI ( $3 \mathrm{mg} / \mathrm{kg}$ body weight, subcutaneously) showed a significant $(p<0.05)$ reduction in ankle width and histological parameters when compared with the disease control group in this model (fig 6 and fig 7). In the second phase of the study, PEG sTNF-RI was administered to SCW challenged rats in a dose related fashion $(0.1 \mathrm{~m} / \mathrm{kg}-3 \mathrm{mg} / \mathrm{kg}$ body weight subcutaneously). Significantly $(\mathrm{p}<0.05)$ reduced swelling in comparison with the disease-control rats occurred to +3 days after injection at the highest doses (fig 8). Mean histology scores were significantly $(p<0.05)$ different for PEG sTNF-RI treated rats at the high dose groups when compared with disease controls (fig 9). These data suggest that PEG sTNF-RI is highly efficacious in a rodent RA model that mimics acute flares in human RA. 


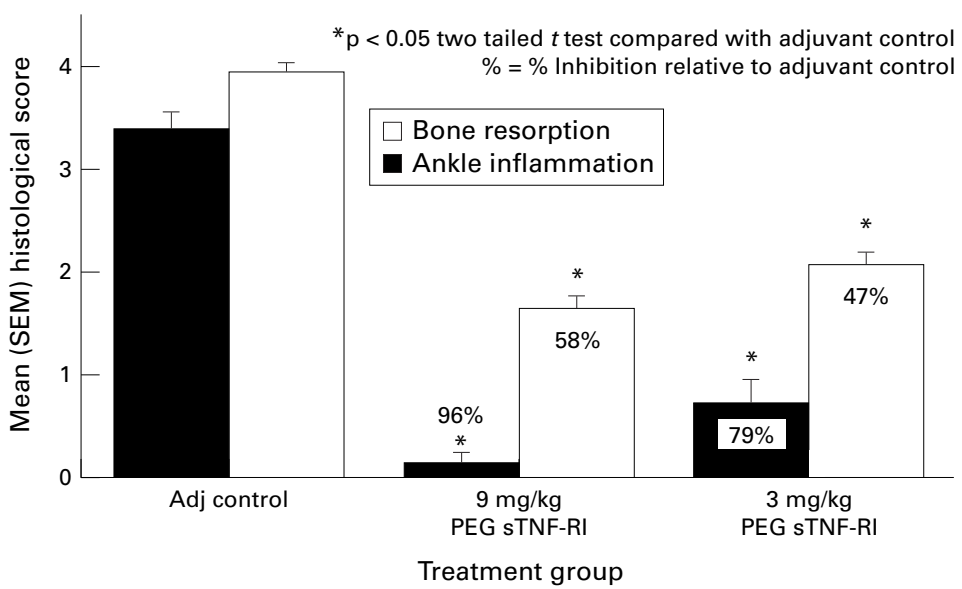

Figure 5 Effects of PEG sTNF-RI on histological scores in adjuvant arthritis in male Lewis rats.

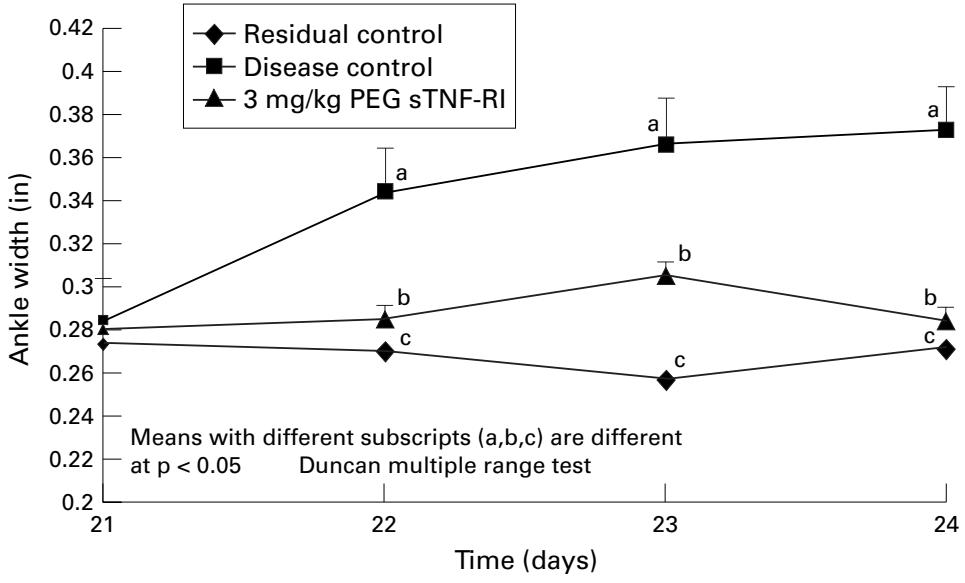

Figure 6 Effects of PEG sTNF-RI (3 $\mathrm{mg} / \mathrm{kg}$ ) on streptococcal cell wall induced arthritis.

Interpretation of results and conclusions from rodent models of $R A$

Results of preclinical studies in rat arthritis models demonstrate that efficacy occurs at doses of PEG sTNF-RI as low as $0.3 \mathrm{mg} / \mathrm{kg}$ given every other day. This dose results in plasma concentrations of $0.3-0.5 \mu \mathrm{g} / \mathrm{ml}$ over the 48 hour dosing interval. Higher doses with higher plasma concentrations demonstrate the dose responsive efficacy on clinical parameters such as joint swelling as well as the important histological parameter of bone destruction. Maximal effects occur when plasma concentrations are maintained in the range of 3-5 $\mu \mathrm{g} / \mathrm{ml}$ (based on continuous infusion studies with monomeric TNF-RI). Additive combination benefit occurs when PEG sTNF-RI is given at these same doses with IL1ra, methotrexate, indomethacin, or dexamethasone. Taken together, these results in preclinical models of arthritis suggest that PEG sTNF-RI should have anti-arthritic activity in patients when plasma concentrations are in the 0.3 to $5 \mu \mathrm{g} / \mathrm{ml}$ range. ${ }^{212371}$ Combination studies with currently used anti-rheumatic agents suggest a strong potential for additive benefit.

\section{Pharmacokinetics and metabolism in animals}

Studies have been performed in mice, rats, cynomolgus monkeys, baboons, and chimpanzees to define the plasma pharmacokinetics of PEG sTNF-RI. ${ }^{72}$ Multiple dose studies were conducted to determine dose and time linearity and any changes over time in PEG sTNF-RI plasma concentrations that could be related to the production of antibodies. In all of the species studied (except mice), the elimination of PEG sTNF-RI from plasma was biphasic, thus both alpha and beta half lives are presented in table 3. It is important to note that a significant portion of the dose is eliminated by the alpha phase in the higher species, particularly in chimpanzees, and thus predicted to occur in humans. Absorption from a subcutaneous dose was slow, with the time to reach maximal plasma concentrations of $24-48$ hours in rats, 36 hours in monkeys, and 12-48 hours in chimpanzees. Systemic bioavailability after a subcutaneous dose of PEG sTNF-RI in rats

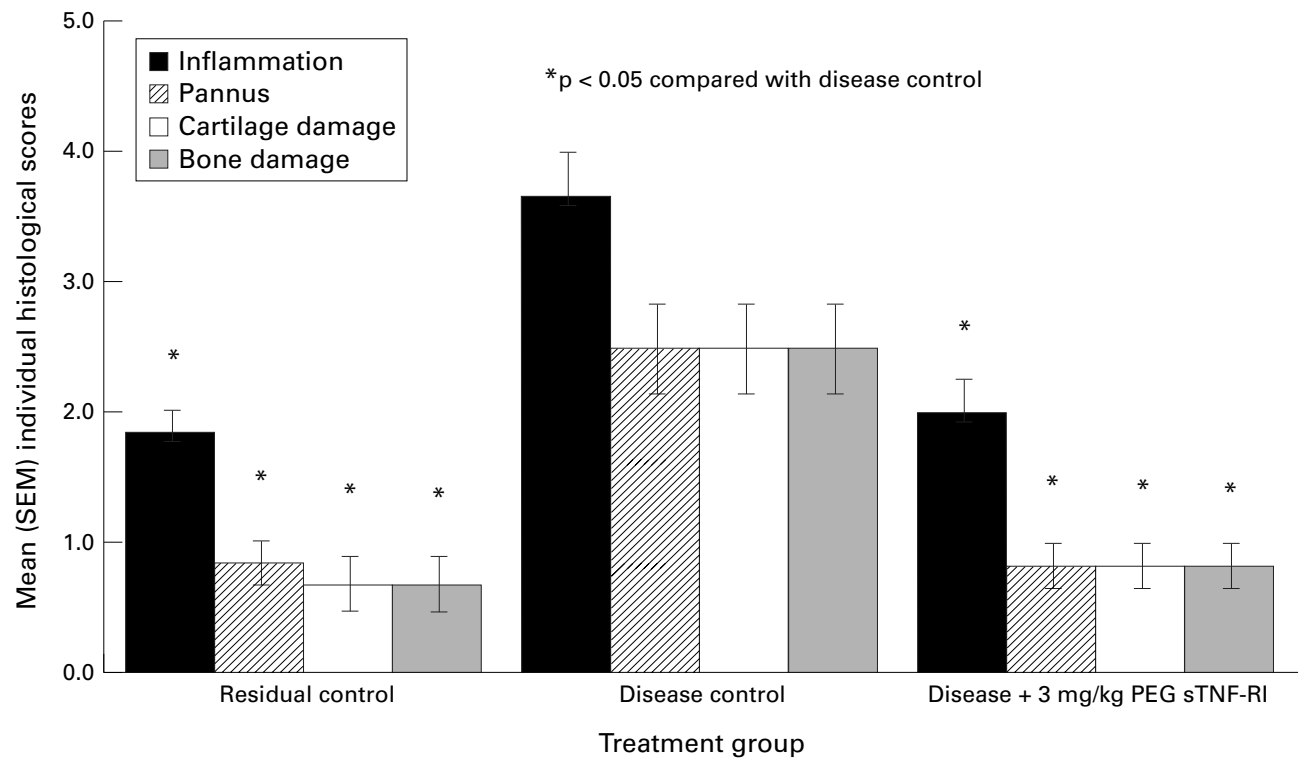

Figure 7 Effects of PEG sTNF-RI (3 $\mathrm{mg} / \mathrm{kg}$ ) on streptococcal cell wall induced arthritis in female Lewis rats (histological scores). 


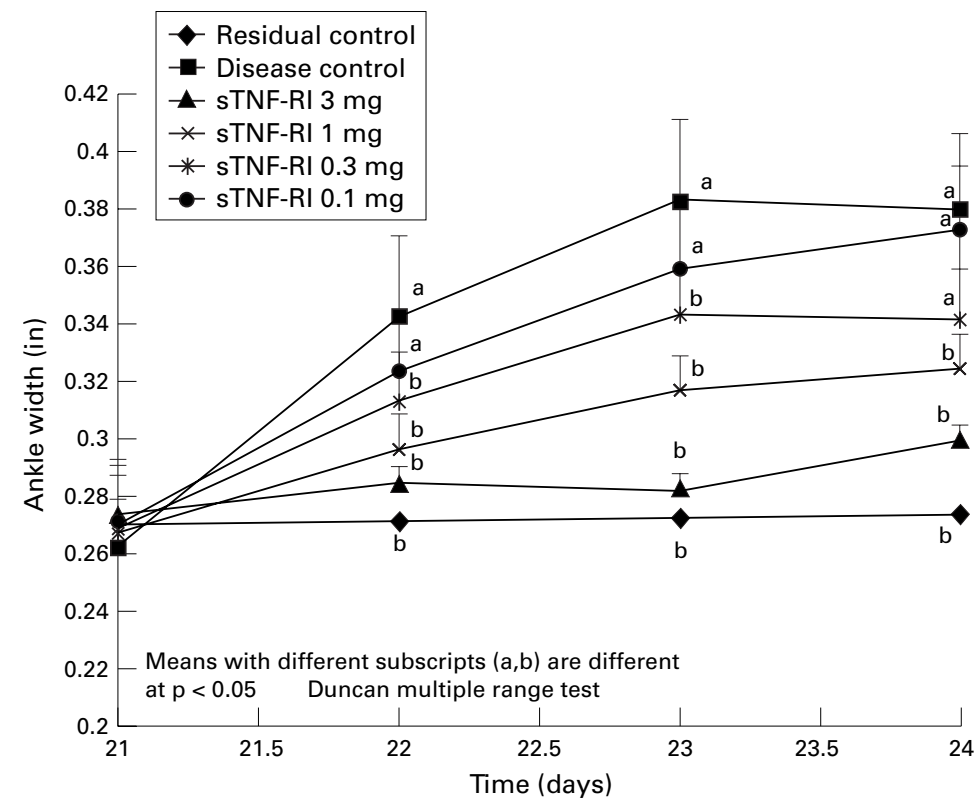

Figure 8 Dose related inhibition of paw swelling by sTNF-RI in streptococcal cell wall induced arthritis in female Lewis rats. and monkeys was determined to be $70 \%$ in rats and approximately $100 \%$ in monkeys. The initial volume of distribution $(\mathrm{Vd})$ in rats, monkeys, baboons and chimpanzees $(\mathrm{Vd} / \mathrm{F}$, where $\mathrm{F}$ is the systemic bioavailability) was essentially equivalent to that of plasma (40 $\mathrm{ml} / \mathrm{kg}$ ). At steady state, the volume of distribution was less than $200 \mathrm{ml} / \mathrm{kg}$ in all species studied (table $3^{72}$ ). This suggests that PEG sTNF-RI does not distribute extensively outside of the plasma compartment. Average plasma clearance in all species was much less than the renal filtration rate, indicating other routes of elimination may be important. The volume of distribution and plasma clearance across species on a per body weight basis was relatively constant. This is consistent with the correlation observed between elimination half lives and body weight. Thus, a $70 \mathrm{~kg}$ human is predicted to distribute and eliminate PEG
sTNF-RI very much like a $50 \mathrm{~kg}$ chimpanzee. Given these data, the dose and dose schedules for the first clinical trial in humans have been projected based on the pharmacokinetic model of PEG sTNF-RI in chimpanzees.

Upon multiple dosing in primates, PEG sTNF-RI was observed to follow both time and dose linear plasma pharmacokinetics with respect to maximal plasma concentrations, area under the plasma concentration versus time curves, and plasma clearance. PEG sTNF-RI did not accumulate in the plasma of baboons administered a $0.2 \mathrm{mg} / \mathrm{kg}$ intravenous dose every three weeks (total of three doses), or in the plasma of cynomolgus monkeys given twice weekly subcutaneous injections ranging from $0.25 \mathrm{mg} / \mathrm{kg}$ to $25 \mathrm{mg} / \mathrm{kg}$ PEG sTNF-RI for four weeks (total of eight doses). In chimpanzees given weekly or twice weekly subcutaneous 0.5 $\mathrm{mg} / \mathrm{kg}$ doses (total of four doses), mild to moderate accumulation was observed. Antibodies to PEG sTNF-RI were not detected in the serum of any of the primate species after either single or multiple doses (fig $10^{72}$ ).

\section{Projections for human dosing based on} preclinical studies

The volume of distribution and plasma clearance of protein pharmaceuticals over a wide molecular weight range (6000 to 98000 Daltons) seem to follow well defined, size related physiological relations, and preclinical pharmacokinetic studies provide reasonable estimates of human disposition after interspecies scaling. The plasma clearance data for PEG sTNF-RI can be scaled from rats and baboons to predict the pharmacokinetics in humans (fig $11^{73}$ ). However, as chimpanzees (Pan troglodytes) are the closest relative to humans and are of a similar body weight (50 $\mathrm{kg}$ ) the pharmacokinetics in chimpanzees would be expected to be similar to those in humans. For a $70 \mathrm{~kg}$ human, one would predict the initial volume of distribution of $60-70$ $\mathrm{ml} / \mathrm{kg}$, a steady state distribution volume of

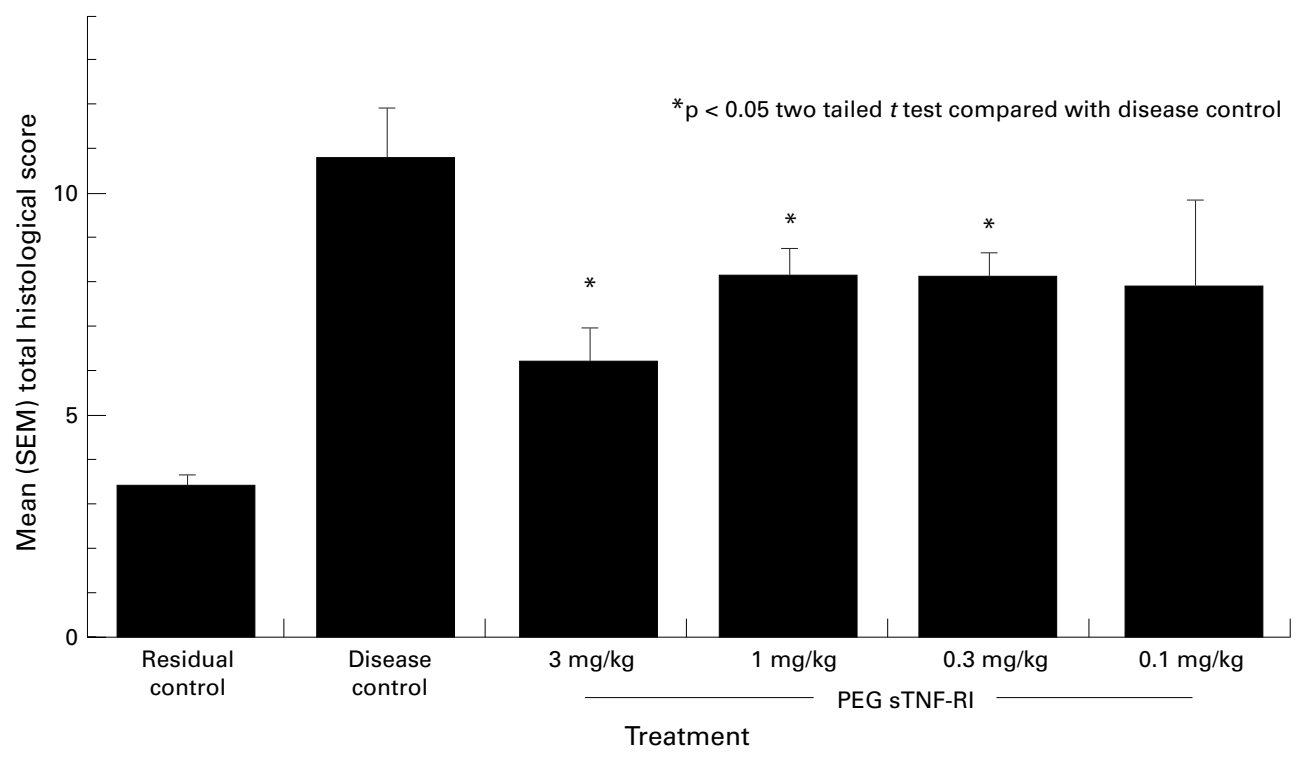

Figure 9 Effects of PEG sTNF-RI on streptococcal cell wall arthritis in female Lewis rats (histological score). 
Table 3 Summary of preclinical single dose pharmacokinetics of PEG sTNF-RI*

\begin{tabular}{llllll}
\hline Species (sex) & $\begin{array}{l}\text { Mouse } \\
(M)\end{array}$ & $\begin{array}{l}\text { Rat } \\
(M / F)\end{array}$ & $\begin{array}{l}\text { Monkey } \\
(M / F)\end{array}$ & $\begin{array}{l}\text { Baboon } \\
(M)\end{array}$ & $\begin{array}{l}\text { Chimpanzee } \\
(F)\end{array}$ \\
\hline Absorption half life (h) & 13 & 10 & $\mathrm{ND}$ & $\mathrm{ND}$ & $3-29$ \\
Alpha phase half life (h) & 4.1 & 3.8 & 9.7 & 9.6 & $20-33$ \\
Beta phase half life (h) & 4.1 & 20 & 29 & 53 & $169-197$ \\
Initial volume (ml/kg) & $74 \dagger$ & 39 & 86 & 47 & $44-66 \dagger$ \\
Vss (ml/kg) & $\mathrm{ND}$ & 68 & 143 & 91 & $56-192 \dagger$ \\
Clearance (ml/h/kg) & $10.4 \dagger$ & 4.0 & 2.81 & 2.2 & $1.1 \dagger$ \\
Absolute SC bioavailability (F) & $\mathrm{ND}$ & $70 \%$ & about $100 \%$ & $\mathrm{ND}$ & $\mathrm{ND}$
\end{tabular}

${ }^{\star}$ In cases where both intravenous and subcutaneous routes have been studied, only the parameters derived from the intravenous route are presented. †Values $=$ indicates parameter $/ F$. ND $=$ not determined.

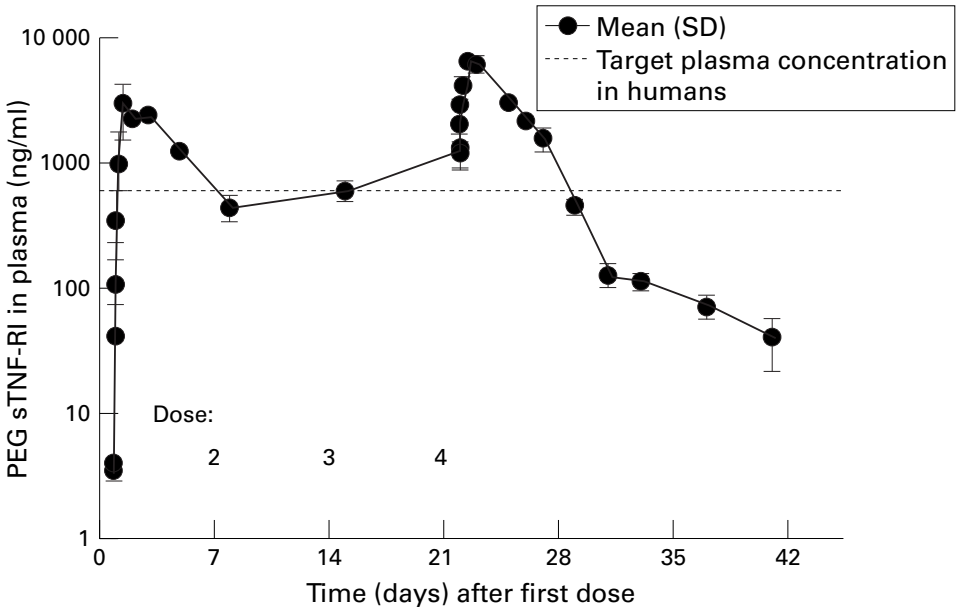

Figure 10 Pharmacokinetic profile of PEG sTNF-RI after multiple subcutaneous injections in female chimpanzees.

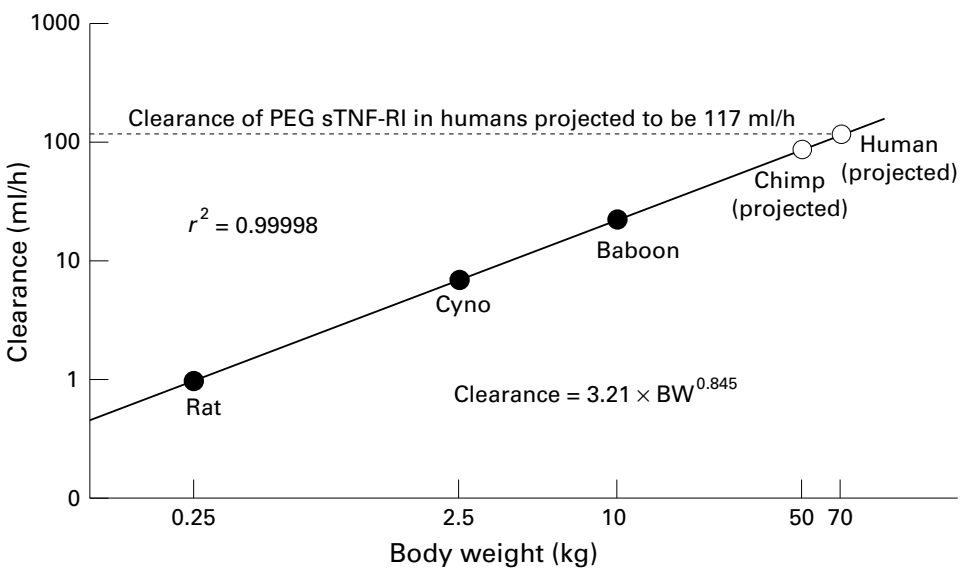

Figure 11 Allometric scaling of clearance.

$80-90 \mathrm{ml} / \mathrm{kg}$ and a plasma clearance of 1.0 to $1.5 \mathrm{ml} / \mathrm{h} / \mathrm{kg}^{73}$

\section{Summary}

Based on the results from our preliminary pharmacology, pharmacokinetic, and toxicology studies, as well as other recently published studies demonstrating clinical proof of concept with anti-TNF compounds, ${ }^{63} 65$ the initial clinical target of PEG sTNF-RI will be RA. A phase 1 study with PEG sTNF-RI has been conducted that is designed as a dose escalating pharmacokinetic trial in RA patients. This trial uses both weekly and bimonthly subcutaneous dosing regimens to assess the safety, immunogenicity, and potential efficacy in RA patients. ${ }^{74}$
1 Carswell EA, Old LJ, Kassel RL, Green S, Fiore N, Williamson B. An endotoxin-induced serum factor that causes necrosis of tumors. Proc Natl Acad SciUSA

2 Tracey KJ. TNF and Mae West or: death from too much of a good thing. Lancet [commentary]. 1995;345:75-6.

3 Bazzoni F, Beutler B. The tumor necrosis factor ligand and receptor families. N Engl J Med 1996;334:1717-25.

4 Brennan FM, Maini RN, Feldmann M. Role of proinflammatory cytokines in rheumatoid arthritis. Springer Semin Immunopathol 1998;20:133-47.

5 Firestein GS, Zvaifler N. Anticytokine therapy in rheumatoid arthritis. N Engl J Med 1997;337:195-7.

6 Beutler B, Cerami A. The biology of cachectin/TNF-a primary mediator of the host response. Annu Rev Immunol 1989;7:625-55.

7 Edwards III CK, Borcherding S, Zhang J, Borcherding DR, Laskin DL. Role of tumor necrosis factor-alpha (TNFalpha) in acute and chronic inflammatory responses: novel therapeutic approaches. In: Schook LB, ed. Xenobiotic induced inflammation: roles of cytokines and growth factors. New York NY: Academic Press, 1994:97-147.

8 Evans TJ, Moyes D, Carpenter A, et al. Protective effect of $55-\mathrm{Kd}$ but not $75-\mathrm{Kd}$ soluble tumor-necrosis-factor receptor immunoglobulin-G fusion proteins in an animal-mode of Gram-negative sepsis. J Exp Med 1994;180:2173-9.

9 Fisher Jr CJ, Agosti JM, Opal SM, et al. Treatment of septic shock with the tumor necrosis factor receptor: Fc fusion protein. N Engl J Med 1996;334:1697-702.

10 Beutler BA. The role of tumor necrosis factor in health and disease. J Rheumatol 1999;26:16-21.

11 Feldmann M, Brennan F, Paleolog E, Taylor P, Maini RN. Anti-tumor necrosis factor alpha therapy of rheumatoid arthritis. Eur Cytokine Netw 1997;8:297-300.

12 Beutler B, Van Huffel C. Unraveling function in the TNF ligand and receptor families. Science 1994;264:667-709.

13 Banner DW, D'Arcy A, Janes W, et al. Crystal structure of the soluble human $55 \mathrm{kd}$ TNF receptor-human TNF beta complex: implications for TNF receptor activation. Cell 1993;73:431-45.

14 Suda T, Takahashi T, Golstein P, Nagata S. Molecular cloning and expression of the Fas ligand, a novel member of the tumor necrosis factor family. Cell 1993;75:1169-78.

15 Grell M, Wajant H, Zimmerman G, Scheurich P. The type I receptor (CD120a) is the high-afte Acad Sci USA 1998;95. tumor

16 Watts $\mathrm{AD}$, Hunt $\mathrm{NH}$, Wanigasekara $\mathrm{Y}$, et al. A casein kinase I motif present in the cytoplasmic domain of members of the tumour necrosis factor ligand family is implicated in 'reverse signalling'. EMBO J 1999;18:2119-26.

17 Cope AP, Maini RN. Soluble tumor necrosis factor receptors in arthritis. J.Rheumatol. 1995;22:382-4

18 Kohno T, Brewer MT, Baker SL, et al. A second tumor necrosis factor gene product can yield a naturally occuring tumor necrosis factor inhibitor. Proc Natl Acad Sci USA 1990;87:8331-5.

19 Van Zee KJ, Kohno T, Fischer E, Rock CS, Moldawer LL, Lowry SF. Tumor necrosis factor soluble receptors circulate during experimental and clinical inflammation and can protect against excessive tumor necrosis factor alpha in vitro and in vivo. Proc Natl Acad Sci USA 1992;89:4845-9.

20 Bendele A, McComb J, Gould T, et al. Animal models of arthritis: relevance to human disease. Toxicol Pathol 1999; 27:134-42.

21 Bendele AM, McComb J, Gould T, et al. Combination benefit of PEGylated soluble tumor necrosis factor receptor type I (PEG sTNF-RI) and dexamethasone or indomethacin in adjuvant arthritic rats. Inflamm Res 1999;48:45360 .

22 Bendele AM, McComb J, Gould T, et al. Effects of PEGylated soluble tumor necrosis factor receptor type I (PEG sTNF-RI) alone ands in combination with methotrexate in adjuvant arthritic rats. Clin Exp Rheumatol (in press).

23 McComb J, Gould T, Chlipala E, et al. Anti-arthritic activity of soluble TNF receptor forms in adjuvant arthritis: correlation of plasma levels with efficacy. J Rheumatol 1999;26:1347-51.

24 Elliott MJ, Maini RN, Feldmann M, et al. Randomised double-blind comparison of chimeric monoclonal antibody to tumour necrosis factor alpha (cA2) versus placebo in the

25 Elliott MJ, Maini RN, Feldmann M, et al. Treatment of rheumatoid arthritis with chimeric monoclonal antibodies to tumor necrosis factor alpha. Arthritis Rheum 1993;36: 1681-90.

26 Elliott MJ, Maini RN, Feldmann M, et al. Repeated therapy with monoclonal-antibody to tumor necrosis factor alpha (cA2) in patients with rheumatoid arthritis. Lancet 1994;344:1125-7.

27 Solorzano C, Kaibara A, Hess PJ, et al. Pharmacokinetics, immunogenicity and efficacy of dimeric TNFR binding proteins in healthy and bacteremic baboon. J Appl Physiol 1998;84:1119-30.

28 Yang SP, Edwards III CK, Mountz JD. Soluble TNF receptor prevents arthritis and pneumonitis in motheaten mice. Arthritis Rheum 1998;41:139-49.

29 Russell D, Tucker H, Kohno H, Thompson RC. Inhibition of tumor necrosis factor (TNF) is effective alone or in combination with inhibition of interleukin-1 (IL-1) in reducing joint swelling in rodent bacterial cell wall-induced arthritis. Arthritis Rheum 1996;37:s279. 
30 Espat NJ, Cendan JC, Beierle EA, et al. PEG-BP-30 monotherapy attenuates the cytokine-mediated inflammatory cascade in baboon Escherichia coli septic shock. JSurg Res 1995;59:153-8.

31 Solorzano CC, Ksontini R, Pruitt JH, et al. Involvement of $26-\mathrm{kDa}$ cell associated $\mathrm{TNF} \alpha$ in experimental hepatitis and exacerbation of liver injury with a matrix metalloproteinase inhibitor. J Immunol 1997;158:414-19.

32 Milani RV, Mehra MR, Endres S, et al. The clinical relevance of circulating tumor necrosis factor-alpha in acute decompensated chronic heart failure without cachexia. Chest 1996;110:992-5.

33 Marriott JB, Westby M, Dalgleish A. Therapeutic potential of TNF- $\alpha$ inhibitors old and new. Drug Developmen Today $1997 ; 2: 273-81$

34 Van Zee KJ, Moldawer LL, Oldenburg HS, et al. Protection against lethal Escherichia bacteremia in baboons (Papio anubis) by pretreatment with a $55-\mathrm{kDa}$ TNF receptor (CD120a)-Ig fusion protein, Ro 45-2081. J Immunol 1996; 156:2221-30

35 Fisher CJ Jr, Agosti JM, Opal SM, Lowry SF, Balk RA, Sadoff JC. Treatment of septic shock with the tumor necrosis factor receptor:Fc. N Engl J Med 1996;334:1697-702.

36 Abraham E, Glauser MP, Butler T, et al. p55 tumor necrosis factor receptor fusion protein in the treatment of patients with severe sepsis and septic shock. A randomized controlled multicenter trial. JAMA 1997;277:1531-8

37 Moreland LW. Inhibitors of tumor necrosis factor for rheumatoid arthritis. J Rheumatol 1999;26:7-15.

38 Aderka D, Engelmann H, Maor Y, Brakebusch C, Wallach D. Stabilization of the bioactivity of tumor necrosis factor by its soluble receptors. J Exp Med 1992;175:323-9.

39 Mohler KM, Torrance DS, Smith CA, et al. Soluble tumor necrosis factor (TNF) receptors are effective therapeutic agents in lethal endotoxemia and function simultaneously as both TNF carriers and TNF antagonists. J Immunol 1993;151:1548-61.

40 Tartaglia LA, Pennica D, Goeddel DV. Ligand passing: the $75-$ Kd tumor necrosis factor (TNF) receptor recrutis TNF
for signaling by the $55 \mathrm{Kd}$ TNF receptor. J Biol Chem for signaling by the

41 Ksontini R, MacKay SL, Moldawer LL. Revisiting the role of tumor necrosis factor alpha and the response to surgical injury and inflammation. Arch Surg 1999;133:558-67.

42 Grau G E, Maennel DN. TNF inhibition and sepsissounding a cautionary note. Nat Med 1997;3:1193-5.

43 Lorenz HM, Kalden JR. Biologic agents in the treatment of inflammatory rheumatic diseases. Curr Opin Rheumatol 1999;11:179-84

44 Dayer J, Burger D. Interleukin-1, tumor necrosis factor and their specific inhibitors. European Cytokine Review 1994;5:563-71

45 Arend WP, Dayer JM. Cytokines and cytokine inhibitors or antagonists in rheumatoid arthritis. Arthritis Rheum 1990; 33:305-15.

46 Arend WP, Dayer JM. Inhibition of the production and effects of interleukin-1 and tumor necrosis factor alpha in rheumatoid arthritis. Arthritis Rheum 1995;38:151-60.

47 Cope AP. Regulation of autoimmunity by proinflammatory cytokines. Curr Opin Immunol 1998;10:669-76.

48 Feldmann M, Brennan FM, Chantry D, et al. Cytokine production in the rheumatoid joint: implications for treatment. Ann Rheum Dis 1990;49:480-6.

49 Butler DM, Malfait A, Mason LJ, et al. DBA/1 mice expressing the human TNF-alpha transgene develop a severe, erosive arthritis. J Immunol 1997;159:2876.

50 Alsalameh S, Winter K, Al-Ward R, Wendler J, Kalden JR, Kinne RW. Distribution of TNF-alpha, TNF-R55 and TNF-R75 in the rheumatoid synovial membrane: TNF receptors are localized preferentially in the lining layer; TNF-alpha is distributed mainly in the vicinity of TNF receptors in the deeper layers. Scand J Immunol 1999;49: $278-85$.

51 Hale KK, Smith CG, Baker SL, et al. Multifunctional regulation of the biological effects of TNF-alpha by the soluble

type I and type II TNF receptors. Cytokine 1995;7:26-38. origins of soluble interleukin 6 receptor-alpha in serum and synovial fluid. J Rheumatol 1997;24:1510-16.

53 Brennan FM, Gibbons DL, Cope AP, Katsikis P, Maini RN, Feldmann $M$. TNF inhibitors are produced spontaneously by rheumatoid and osteoarthritic synovial joint cel cultures: evidence of feedback control of TNF action. Scand J Immunol 1995;42:158-65.
54 Felson DT, Anderson JJ, Boers M, et al. American College of Rheumatology. Preliminary definition of improvement in reumatoid arthritis. Arthritis Rheum 1995;38:727-35.

55 Felson DT, Anderson JK, Lange ML, Wells G, LaValley MP. Should improvement in rheumatoid arthritis clinical trials be defined as fifty percent or seventy percent improvements in core set measures, rather than twenty percent? Arthritis Rheum 1998;41:1564-70.

56 Feldmann $M$. What is the mechanism of action of anti-tumour necrosis factor-alpha antibody in rheumatoid arthritis? Int Arch Allergy Immunol 1996;111:362-5.

57 Feldmann M, Brennan FM, Maini RN. Rheumatoid arthritis. Cell 1996;85:307-10.

58 Maini RN, Elliott M, Brennan FM, Williams RO, Feldmann $M$. TNF blockade in rheumatoid arthritis: implications for therapy and pathogenesis. APMIS 1997;105:257-63.

59 Feldmann M, Brennan FM, Maini RN. Role of cytokines in rheumatoid arthritis. Annu Rev Immunol 1996;14:397-440.

60 Choy EHS, Panayi GS. Engineered human anti-tumor necrosis factor-alpha (TNF $\alpha$ ) antibody, CDP571, in rheumatoid arthritis. In: Strand V, Scott DL, Simons LS, eds. Novel therapeutic agents for the treatment of autoimmune diseases. New York, NY: Marcel Dekker, 1997:121-9.

61 Sander O, Rau R. Clinical trials on biologics in rheumatoid arthritis. Int J Clin Pharmacol Ther 1998;36:621-4.

62 Moreland LW, Baumgartner SW, Schiff MH, et al. Treatment of rheumatoid arthritis with a recombinant human tumor necrosis factor receptor (p75)-Fc fusion protein. N Engl J Med 1997;337:141-7.

63 Moreland LW, Schiff $\mathrm{MH}$, Baumgartner SW, et al. Etanercept therapy in rheumatoid arthritis: A randomized, controlled trial. Ann Intern Med 1999;130:478-86.

64 Feldmann M, Elliott MJ, Woody JN, Maini RN. Anti- tumor necrosis factor-alpha therapy of rheumatoid arthritis. Adv Immunol 1996; 64:283-350.

65 Moreland LW, McCabe D, Caldwell JR, et al. Recombinant methionyl human tumor necrosis factor binding protein PEGylated dimer (TNFbp Dimer) in patients with active refractory rheumatoid arthritis. J Rheumatol (in press).

66 Edwards III CK, Frazier J, Seely J, et al. Assessment of the major antigenic epitopes of the recombinant human soluble p 55 TNF type I receptor: design of a novel monomeric non-immunogenic analog, sTNF-RI. Arthritis Rheum 1998;41:S58.

67 Parmely MJ, Zhou WW, Edwards III CK, Borcherding DR, Silverstein R, Morrison DC. Adenosine and a related carbocyclic nucleoside analogue selectively inhibit tumor necrosis factor-alpha production and protect mice against endotoxin challenge. J Immunol 1993;151:389-96.

68 Burger D, Chicheportiche R, Giri JG, Dayer J. The inhibitory activity of human interleukin-1 receptor antagonist is enhanced by type II interleukin- 1 soluble receptor and hindered by type I interleukin-1 soluble receptor. J Clin Invest 1995;96:38-41.

69 Esser RE, Stimpson SA, Cromartie WJ, Schwab JH. Reactivation of streptococcal cell wall-induced arthritis by homologous cell wall polymers. Arthritis Rheum 1985;28: 1402-11.

70 Evans RJ, Bendele AM, Kieft GL, McAbee TJ, Edwards III CK. Efficacy of tumor necrosis factor binding protein (TNF-bp) in the streptococcal cell wall-induced reactivation model of arthritis. Arthritis Rheum 1996;39:S284

71 Bendele A, McAbee T, Sennello G, Frazier J, Chlipala E, McCabe D. Efficacy of sustained blood levels of interleukin-1 receptor antagonist in animal models of arthritis. Arthritis Rheum 1999;42:498-506.

72 Martin S, Frazier J, Seely J, et al. A genetically modified tumor necrosis factor receptor I (sTNF-RI) that does not elicit antibody response in primates. Arthritis Rheum 1998;41:S58.

73 Martin SW, Sommers JS, Macri MJ, et al. The Pharmacokinetics of subcutaneous injections of PEGylated recombinant methiopnyl human soluble tumor necrosis factortype I receptor (PEG sTNF-RI) in subjects with active rheumatoid arthritis. Arthritis Rheum (in press)

74 Caldwell JR, Davis MW, Jelaca-Maxwell K, et al. A phase 1 study of PEGylated soluble tumor necrosis factor receptor type I (PEG sTNF-RI [p55]) in subjects with rheumatoid arthritis (RA). Arthritis Rheum (in press) 